\title{
PERAN MEDIA ARUS UTAMA DALAM MEMUBLIKASIKAN PRODUK MAKANAN HALAL
}

\author{
Suyono \\ Program Studi Ilmu Komunikasi - Fakultas Ilmu Sosial dan Ilmu Politik \\ Universitas Muhammadiyah Jember \\ Jalan Karimata No. 49, Telp. 0331- 336728, Jember 68121 \\ Email: suyono.sulaiman@unmuhjember.ac.id
}

\begin{abstract}
This study uses a qualitative descriptive approach, by observing / observing related mainstream Media roles in publishing Halal food products. Refer to the Law (UU) Number 33 year 2014 on the Halal Product Guarantee (JPH), which will be effective 17 October 2019, then food products, beverages, and other products that are circulating and traded in the region of Indonesia must be certified Halal. Halal products are products (food, beverages, etc.) that are processed and produced halal. The same is the case with materials and the process should also be halal. Halal Certificate In fact protects Muslim consumers against unkosher products and beverages, provides a sense of security and comfort to consume them, because there is no doubt that the product is indicative of the things that are haraam According to Islamic law. Although the validity period has lived a few more months, but the reverb enforcement of the law No. 33/2014, not yet loud heard in the community. Hence, the authors are interested in researching how much mainstream media roles (mainstream media, especially newspapers and television) are participating in publishing halal product guarantees, in the announcement. From the author's research, apparently mainstream media has not contributed much in the community to realize the production and also consume halal products. Although some food producers, drinks and beauty equipment, have been conducting socialization activities through advertising in the media, especially on television, by listing the halal logo from LPPOMMUI, in the ad packaging that served.
\end{abstract}

Keywords: the role of mainstream Media, Media publications, Halal food products

\begin{abstract}
Abstrak
Penelitian ini menggunakan pendekatan deskriptif kualitatif, dengan melakukan pengamatan/observasi terkait Peran Media Arus Utama Dalam Memublikasikan Produk Makanan Halal. Merujuk Undang-Undang (UU) Nomor 33 Tahun 2014 tentang Jaminan Produk Halal (JPH), yang akan berlaku efektif 17 Oktober 2019, maka produk makanan, minuman, dan produk lainnya yang beredar dan diperdagangkan di wilayah Indonesia harus bersertifikat halal.Produk halal adalah produk (makanan, minuman, dan lain-lain) yang diolah dan diproduksi secara halal. Demikian halnya dengan bahan dan prosesnya juga harus halal. Sertifikat Halal hakikatnya melindungi konsumen muslim terhadap produk maknan dan minuman yang tidak halal, memberikan rasa aman dan nyaman untuk mengkonsumsinya, karena tidak ada keraguan lagi bahwa produk tersebut terindikasi dari hal - hal yang di haramkan sesuai syariat Islam. Meski masa berlakunya sudah tinggal beberapa bulan lagi, namun gaung pemberlakukan UU No.33/2014 ini, belum nyaring terdengar di masyarakat. Karenanya, penulis tertarik meneliti seberapa besar
\end{abstract}


peran media arus utama (media mainstream, terutama surat kabar dan televisi) dalam ikut serta memublikasikan jaminan produk halal, dalam pemberitaannya. Dari penelitian penulis, ternyata media arus utama belum banyak berkontribusi dalam menyadarkan masyarakat memproduksi dan juga mengonsumsi produk halal. Meski sebagian produsen makanan, minuman dan alat kecantikan, sudah melakukan kegiatan sosialisasi melalui iklan di media, khususnya di televisi, dengan mencantumkan logo halal dari LPPOMMUI, dalam kemasan iklan yang ditayangkan.

Kata kunci: Peran Media Arus Utama, Publikasi Media, Produk Makanan Halal

\section{Pendahuluan}

Pemerintah sudah membuat ketentuan tentang Jaminan Produk Halal, melalui Undang-Undang (UU) Nomor 33 Tahun 2014, tertanggal 17 Oktober 2014. Setelah disosialisasikan selama lima tahun, setidaknya terhitung 17 Oktober 2019 mendatang, seluruh produk makanan, minuman, obat-obatan, dan produk lainnya, yang beredar di masyarakat harus memenuhi ketentuan dan persyaratan produk halal.

Apa yang dimaksud produk halal? Sesuai ketentuan UU No. 33/2014, yang dimaksud produk halal adalah rangkaian kegiatan untuk menjamin kehalalan suatu produk yang mencakup penyediaan bahan, pengolahan, penyimpanan, pengemasan, penjualan, pendistribusian, dan penyajian produk. Dan undang-undang tersebut menegaskan bahwa kehalalan suatu produk harus dibuktikan dengan diterbitkannya sertifikat halal yang dikeluarkan oleh lembaga berwenang yang ditunjuk pemerintah. Dalam hal ini
Lembaga Pengkajian Pangan, Obatobatan, dan Kosmetika - Majelis Ulama Indonesia (LPPOM-MUI).

Pertanyaannya, sudah siapkah para produsen dan juga pedagang produk makanan, minuman, obat-obatan, kosmetik dan bahan pangan lainnya, menghadapi pemberlakuan undangundang tersebut. Dan masyarakat konsumen di Indonesia, apakah sudah paham dengan hak-haknya, sehingga mereka mengerti dan sadar bahwa produk makanan, minuman, dan produk lainnya yang dikonsumsi sudah terjamin kehalalannya.

Secara umum Negara kita sebenarnya sudah siap melaksanakan ketentuan UU No.33/2014 ini. Mengingat, pemerintah juga sudah lama menunjuk Majelis Ulama Indonesia (MUI) sebagai Badan Penyelenggara Jaminan Produk Halal (BPJPH). Dan hasil kajian BPJPH yang dilaksakan oleh LPPOM-MUI, telah pula diimplementasikan oleh lebih dari 43 lembaga dunia dari 22 negara. Meski 
demikian, budaya dan sistem halal di Negara kita selama ini, seperti masih belum terbangun dengan kokoh. (Khairrunnisa Musari-Radar Jember; $8 / 12 / 2018)$

Terbukti kesadaran masyarakat produsen maupun konsumen terhadap produk halal, sejauh ini belum minded. Untuk masyarakat produsen, masih belum sepenuhnya mengantongi sertifikat halal, baik untuk produk yang sudah lama beredar, apalagi produk baru. Sebaliknya, masyarakat konsumen juga tidak terlalu menuntut halal-tidaknya produk yang ia konsumsi. Asal tidak terkait dengan isu terkontaminasi "babi" masyarakat konsumen di Indonesia, cukup happy dengan produk apapun, asal layak konsumsi.

Padahal, LPPOM-MUI itu sendiri, sudah bertahun-tahun berfungsi sebagai lembaga yang bertugas untuk meneliti, mengkaji, menganalisa dan memutuskan apakah produk-produk baik pangan dan turunannya, obat-obatan serta produk kosmetika, aman untuk dikonsumsi ditinjau dari sisi kesehatan maupun syariat agama Islam.

Adanya standarisasi halal, tentu akan menambah peluang memperluas jaringan pasar produk Indonesia, tidak hanya di dalam negeri, tapi juga di pasar internasional. Sertifikasi halal sejatinya bukan hanya melindungi masyarakat Muslim, tetapi juga melindungi seluruh masyarakat Indonesia. Karena sertifikasi halal, bukan sekadar bicara simbol agama, tetapi sudah menjadi simbol bagi kualitas, higienitas, kesehatan, dan keamanan bagi konsumen.

BPJPH harus hadir bersama Majelis Ulama Indonesia (MUI) dan stakeholder lainnya untuk menjadikan produk halal sebagai arus baru ekonomi Indonesia dan menjadi pintu gerbang membangun kedaulatan ekonomi rakyat. Betapa tidak, di luar Indonesia, sudah banyak negara yang berbondong-bondong menjadi pusat halal. Indonesia dengan penduduk Muslim terbesar di dunia, tentunya tidak boleh hanya menjadi pasar, tetapi harus menjadi tuan di rumah bagi produknya sendiri.

Ekonomi halal adalah arus baru ekonomi Indonesia dan dunia. Ekonomi halal memiliki potensi mendorong pertumbuhan ekonomi nasional dan global. Saat ini, permintaan konsumen atas produk halal meningkat pesat. Hal ini akan mendongkrak investasi dan perdagangan pada industri halal, baik di negara berpenduduk mayoritas Muslim maupun nonmuslim. Potensi tersebut semakin kuat dengan meningkatnya pertumbuhan populasi Muslim dunia yang diprediksi 
akan mencapai 27,5 persen dari total populasi dunia pada 2030 .

Dalam konteks Indonesia, ketaatan atas agama yang semakin baik menjadi salah satu pemicunya. Hal ini terindikasi dari fenomena perilaku konsumen Muslim di Indonesia yang menunjukkan pola konsumsi yang semakin peduli akan produk halal. Ditambah lagi kesadaran beragama yang tinggi pada generasi millenial atau generasi Z. Riset Varkey Foundation pada 20 ribu anak muda dari 20 negara yang lahir pada rentang tahun 1995-2001 menunjukkan anak muda di Indonesia menempati peringkat pertama yang menganggap agama penting sebagai kunci kebahagiaan hidup.

Implementasi JPH pada produkproduk Indonesia berpeluang meningkatkan potensi ekspor. Meningkatnya perdagangan global untuk produk halalmenjadi salah satu indikator atas kontribusinya bagi peningkatan pertumbuhan ekonomi nasional. Pemerintah hari ini sangat mendorong peningkatan ekspor produk halal guna turut memperbaiki defisit transaksi berjalan. Sementara, data yang ada pada 2017, ekspor produk halal Indonesia mencapai 21 persen dari total ekspor secara keseluruhan.
Konsekuensinya, dunia usaha berkewajiban memenuhi standar yang telah ditetapkan. Namun, pemerintah juga harus memastikan proses standarisasi tidak membebani pelaku usaha, khususnya pelaku usaha mikro kecil menengah (UMKM). Ketika pemerintah menuntut dunia usaha menghasilkan produk bersertifikasi halal, maka pemerintah juga sebaiknya menjamin proses sertifikasi halal tidak rumit dan tidak mahal.

Persoalannya, meski Undang-Undang Jaminan Produk Halal (JPH) yang sudah diundangkan sejak 17 Oktober 2014, dan akan berlaku efektif beberapa bulan mendatang, ternyata pengetahuan masyarakat, baik kalangan produsen (dunia usaha) maupun masyarakat konsumen terhadap jaminan produk halal, masih minim. Karena itu, dibutuhkan sosialisasi yang lebih massif ke tengah masyarakat. Untuk itu, peran media khususnya media massa arus utama (mainstream) sangat diharapkan dalam membantu mensosialisasikan produk halal, dengan melakukan publikasi yang terus-menerus melalui media massa yang ada, baik media cetak maupun elektronik, seperti radio dan televisi.

\section{Metode Penelitian}

Penelitian ini menggunakan metode deskriptif kualitatif. Menurut 
Sukmadinata (2006:72), penelitian jenis ini merupakan penelitian yang mendeskripsikan dan menginterpretasikan sesuatu, terkait dengan kondisi atau hubungan yang ada, terkait dengan pendapat yang berkembang, proses yang tengah berlangsung, akibat atau efek yang terjadi, atau tentang kecenderungan yang tengah berlangsung. Dalam hal ini, peneliti mencoba mendeskripsikan kecenderungan atau peran media arus utama, terkait dengan publikasi makanan halal.

Fokus penelitian ini pada peran media arus utama, baik media cetak-khusunya Jawa Pos dan Radar Jember, serta media elektronik - televisi nasional (TV One, Trans TV, dan Net TV), terkait dengan publikasi makanan halal, dalam bentuk berita maupun iklan. Untuk mencapai tujuan penelitian kualitatif, peneliti menggunakan teknik pengumpulan data yang khas kualitatif, yakni observasi dan wawancara, disamping memeriksa dokumen, karya-karya tulis subjek, serta publikasi teks. (Herdiansyah, 2010:11)

\section{Hasil Penelitian dan Pembahasan}

Media massa telah menjadi salah satu kekuatan penting abad modern. Revolusi bidang sains dan tehnologi membuat media massa memiliki spektrum yang demikian luas, menjangkau seluruh wilayah, lapisan masyarakat dengan intensitas yang masif. Dalam konteks politik, media massa merupakan salah satu kekuatan politik penting yang memengaruhi proses politik.

Karena itulah keberadaan media massa, terutama pers bebas dianggap sebagai salah satu pilar dari demokrasi. Begitu luar biasanya kekuatan media massa ini digambarkan oleh Malcolm X dengan pernyataan bahwa:"the media's the most powerfull entity on earth. They have the power to make the innocent guilty and to make the guilty innocent, and that's power. Because they control the minds of the masses". Media massa merupakan entitas terkuat di muka bumi karena kemampuannya dalam membentuk dan mengendalikan kesadaran massa. Dengan kekuatan tersebut, media massa bahkan mampu menentukan apa yang baik dan apa yang buruk bagi masyarakat seperti halnya seorang dokter yang mengobati pasiennya.

Media massa, terutama media arus utama (mainstream) dalam kehidupan masyarakat masih mempunyai peran sosial yang cukup besar. McQuail (2000:66), menyatakan bahwa dalam masyarakat modern, ada enam perspektif dalam melihat media massa. Pertama, media massa sebagai window on event and experience. Dalam perspektif ini, media 
dipandang sebagai jendela yang akan menunjukkan arah atau memungkinkan masyarakat melihat apa menerjemahkan berbagai hal, menyangkut yang sedang terjadi di dunia luar. Media juga menjadi sarana belajar untuk mengetahui berbagai peristiwa yang tengah terjadi.

Perspektif kedua, media dianggap sebagai a mirror of event ini society and the world, implying a faithful reflection. Sebagai cermin, media berfungsi merefleksikan setiap peristiwa yang terjadi di belahan dunia secara apa adanya. Implikasinya, pihak pengelola media sering merasa tidak masalah, kalau isi pemberitaannya tidak seluruhnya berisi hal-hal yang mendidik dan hal-hal yang positif lainnya. Karena yang diberitakan pada dasarnya berupa fakta dan peristiwa sesungguhnya.

Ketiga, perspektif media sebagai gatekeeper atau filter. Artinya, media menyeleksi setiap informasi untuk diberi perhatian atau tidak. Media akan memilih setiap isu atau informasi dalam bentuk konten lain berdasar standar pengelolanya. Sehingga khalayaktidakbisa memilih berita apa yang akan dikonsumsinya, karena pilihan itu hanya ada pada pengelola media massa.

Perspektif keempat, media dipandang sebagai guide atau interpreter, yang berfungsi sebagai penunjuk jalan yang ketidakpastian dan alternatif lainnya yang beragam.Kelima, melihat media massa sebagai forum untuk mempresentasikan berbagai ide/gagasan dan berbagai informasi yang memungkinkan terjadinya tanggapan atau umpan balik. Keenam, media diperspektifkan sebagai interlocutor, yang berarti media tidak hanya sekadar menyampaikan informasi, tetapi media juga menjadi partner komunikasi yang memungkinkan terjadinya interaksi antara media dengan khalayak pembacanya.

Media arus utama juga punya peran untuk tumbuh kembangnya budaya di masyarakat. Mengingat, media massa memilki kemampuan untuk memopulerkan sesuatu hingga mampu diapresiasi, dicintai, dan menjadi pegangan hidup masyarakat. Media massajuga mampu meningkatkan kesadaran masyarakat, untuk kembali mengempati kepedulian sosial masyarakat, serta menjadi petunjuk bagi masyarakat untuk melakukan sesuatu atau tidak melakukan sesuatu. Karena itu, media massa punya kedudukan strategis dalam masyarakat.

Penelitian ini dilakukan dengan menganalisis pemberitaan dan juga produk 
iklan yang ditayangkan di media mainstream (media arus utama), untuk media cetak peneliti melakukan pengamatan pada Harian Radar Jember (Jawa Pos Grup). Pengamatan juga dilakukan peneliti pada media elektronik, terutama media televisi nasional, seperti Trans TV, TV One, dan Net TV.

Ada beberapa produk media massa. Produk utama media massa tentunya berita dengan berbagai jenisnya. Diantaranya, berita straight news (berita langsung) yang porsinya cukup besar, terutama untuk media cetak, media elektronik, seperti radio dan televisi, serta media online. Berita jenis ini lebih mengandalkan kecepatan dan kehangatan informasi (aktual), dan menyandarkan informasi dari peristiwa atau kejadian, yang sering disebut fakta (faktual). Selain berita langsung, juga ada beberapa jenis berita lainnya, seperti feature (berita kisah), berita investigasi (investigative reporting), berita mendalam (in depth news), berita ringan (soft news), editorial news, artikel, kolom, karikatur, dan beberapa jenis berita lainnya. Disamping dalam bentuk berita, produk media lainnya adalah iklan. Iklan merupakan produk media yang dijual kepada masyarakat, terutama kalangan dunia usaha, sebagai sarana mempromosikan dan mengenalkan produknya ke khalayak masyarakat. Dengan beriklan, sebuah produk akan lebih dikenal, dan selanjutnya dicintai, serta harapan akhirnya dikonsumsi. Karena itu, sosialisasi dan publikasi produk makanan halal di media massa, bisa berupa pemberitaan maupun dalam bentuk iklan.

Selain mempunyai karakteristik, media massa menurut Badjuri (2010:8687) dalam menurunkan berita, harus sesuai dengan criteria berita yang baik, yakni objektif, yaitu berita harus merupakan laporan faktual tentang suatu peristiwa seperti apa adanya, meski wartawan sendiri juga mempunya banyak keterbatasan. Disamping itu, berita juga harus punya news value atau nilai berita.

Menurut Badjuri, berita dianggap mempunyai nilai, manakala berita tersebut dapat menggugah, menimbulkan rasa simpati, rasa marah, dan sikap lainnya. Karena itu, berita harus mempunyai nilai antara lain:significance (penting bagi masyarakat),timeliness (aktual), proximity (kedekatan dengan pembaca), prominence (menyangkat orang terkemuka), consequence (akibat dari berbagai sebab), conflict (terjadinya konflik), development (berita pembangunan/membangun), disaster and crimes (bencana dan kriminal), human interest (kisah-kisah 
kemanusiaan), dan sport (kegiatan keolahragaan).

Selama periode penelitian, Februari sampai Maret 2019, untuk pemberitaan maupun iklan terkait tema produk makanan halal tidak ditemukan di Harian Radar Jember. Meski ada beberapa berita yang memuat perihal produk makanan di Radar Jember, namun isi pemberitaan tersebut cenderung membahas produk makanan dan minuman sehat, makanan alternatif dan bukan makanan yang berkorelasi dengan kehalalan.

Satu contoh berita di Radar Jember yang diterbitkan 14 Februari 2019 berjudul "Warga Galakkan Industri Makanan Berbahan Ikan.” Berita jenis straight news ini membahas kegiatan kelompok masyarakat yang tengah menggalakkan industri makanan dengan bahan baku ikan. Berita ini sebenarnya relevan dengan pokok bahasan penelitian, namun karena tidak dikaitkan dengan kehalalan bahanbahan yang digunakan, maka berita ini tidak masuk dalam kategori publikasi makanan halal.

Demikian juga dengan berita "Pemuda Desa Bikin Teh Daun Kelor" yang ditayangkan 24 Maret 2019 dan berita dengan judul "Teh Celup Rempah Sukorambi Rambah Jateng,” yang dimuat di harian yang sama edisi 28 Maret 2019. (lihat Tabel: 1) Meski kedua berita tersebut membahas tentang produksi minuman yang menyehatkan dan tentunya halal, karena memanfaatkan bahan-bahan tanaman herbal tanpa tambahan bahan kimia yang berbahaya atau bahan yang diragukan kehalalannya, namun berita ini juga tidak dapat dikategorikan tengah memublikasikan makanan halal. Mengingat, bahasan tentang kehalalan sama sekali tidak disentuh oleh penulis berita.

Karenanya, selama masa penelitian bulan Februari hingga Maret 2019, peneliti tidak menemukan berita atau publikasi di Harian Radar Jember, tentang makanan halal, setidaknya syarat makanan halal menurut ketentuan LPPOM MUI. Meski demikian, Harian Radar Jember, setidaknya dalam satu tahun terakhir menunjukkan peranannya dalam memublikasi makanan halal. Berita-berita dimaksud, ditemukan peneliti, termuat pada beberapa bulan di luar masa penelitian, dalam bentuk berita straight news dan opini atau artikel umum.

Salah satunya, berita yang berjudul "Delapan UMKM Jember Diaudit Halal" tertanggal 27 November 2018. Juga berita dengan tema halal yang berjudul: "Bupati Buka Road to ISEF 2018: Harus Bisa Kembangkan UMKM dan Ekonomi 
Syariah," dimuat (03/12/2018). Untuk berita pertama, memenuhi syarat sebagai bentuk publikasi makanan halal, mengingat berita tersebut membahas UMKM yang memproduksi berbagai produk makanan yang tengah diaudit LPPOM MUI Surabaya, untuk keperluan penerbitan sertifikasi halal. Sehingga, apabila UMKM tersebut dinyatakan lolos sertifikasi, maka produk makanan yang dihasilkan dijamin kehalalannya sesuai standar undang-undang yang berlaku di Negara kita.

Sedang berita kedua, meski tidak sepenuhnya memenuhi syarat sebagai bentuk publikasi makanan halal, namun kegiatan yang didukung Bupati Jember itu, mengarah pada pengembangan UMKM dan kegiatan ekonomi yang berbasis pada ketentuan syariah. Sehingga, kedepannya diharapkan kegiatan usaha UMKM di Jember, sesuai dengan pola ekonomi syariah dan menghasilkan produk-produk yang dijamin kehalalannya.

Berikutnya, pada edisi (08/12/2018) Harian Radar Jember menurunkan berita dalam bentuk artikel umum yang ditulis oleh Khairunnisa Musari, berjudul: “Menuju Ekonomi Halal.” Artikel ini tentu menjadi bagian penting media arus utama, seperti Radar Jember ini, dalam ikut serta memublikasikan produk makanan halal.
Dalam artikel yang ditulis dosen IAIN Jember ini, secara jelas dan terperinci, mengungkap ketentuan-ketentuan produk makanan halal sesuai undang-undang, serta prospek dan kebutuhan makanan halal, setelah Undang-Undang Jaminan Produk Halal (JPH) ini resmi diberlakukan 17 Oktober 2019 mendatang.

Berita selanjutnya yang berjudul: "Dosen dan Mahasiswa Universitas Muhammadiyah Jember Dorong UMKM Ajukan Sertifikat Halal," (lihat Tabel: 2) yang dimuat 17 Januari 2019, juga menjadi bagian dari peran media arus utama, khususnya Radar Jember, dalam memublikasikan produk makanan halal. Dalam berita tersebut, dibahas upaya peran serta perguruan tinggi, dalam hal ini adalah mahasiswa dan dosen Universitas Muhammadiyah Jember, yang melakukan program pengabdian, dengan melatih dan mendorong UMKM untuk memproduksi makanan halal, dan mengajuan audit kehalalannya melalui lembaga yang berkompeten, dalam hal ini LPPOM MUI, sehingga kelak bisa tersertifikasi.

\begin{tabular}{|l|l|l|l|}
\hline No. & $\begin{array}{l}\text { Tanggal } \\
\text { Terbit }\end{array}$ & $\begin{array}{l}\text { Jenis } \\
\text { Berita }\end{array}$ & $\begin{array}{l}\text { Judul } \\
\text { Berita }\end{array}$ \\
\hline 1 & 03 & Berita / & Lomba \\
& $\begin{array}{l}\text { Septemb } \\
\text { er 2018 }\end{array}$ & $\begin{array}{l}\text { News } \\
\text { Cipta Menu } \\
\text { Kudapan } \\
\text { Non Beras }\end{array}$ \\
\hline
\end{tabular}




\begin{tabular}{|c|c|c|c|}
\hline & & & $\begin{array}{l}\text { Non Terigu, } \\
\text { Bikin Menu } \\
\text { Makanan } \\
\text { yang Sehat }\end{array}$ \\
\hline 2 & $\begin{array}{l}14 \\
\text { Februari } \\
2019\end{array}$ & $\begin{array}{l}\text { Berita / } \\
\text { Straight } \\
\text { News }\end{array}$ & $\begin{array}{l}\text { Warga } \\
\text { Galakkan } \\
\text { Industri } \\
\text { Makanan } \\
\text { Berbahan } \\
\text { Ikan }\end{array}$ \\
\hline 3 & $\begin{array}{l}24 \text { Maret } \\
2019\end{array}$ & $\begin{array}{l}\text { Berita / } \\
\text { Straight } \\
\text { News }\end{array}$ & $\begin{array}{l}\text { Pemuda } \\
\text { Desa Bikin } \\
\text { Teh Daun } \\
\text { Kelor }\end{array}$ \\
\hline 4 & $\begin{array}{l}28 \text { Maret } \\
2019\end{array}$ & $\begin{array}{l}\text { Berita / } \\
\text { Straight } \\
\text { News }\end{array}$ & $\begin{array}{l}\text { Teh Celup } \\
\text { Rempah } \\
\text { Sukorambi } \\
\text { Rambah } \\
\text { Jateng }\end{array}$ \\
\hline 5 & $\begin{array}{l}02 \text { April } \\
2019\end{array}$ & $\begin{array}{l}\text { Berita / } \\
\text { Straight } \\
\text { News }\end{array}$ & $\begin{array}{l}\text { Ayo } \\
\text { Kurangi } \\
\text { Makanan } \\
\text { Instan }\end{array}$ \\
\hline 6 & $\begin{array}{l}09 \text { April } \\
2019\end{array}$ & $\begin{array}{l}\text { Berita / } \\
\text { Straight } \\
\text { News }\end{array}$ & $\begin{array}{l}\text { Jamur } \\
\text { Krispi } \\
\text { Jember } \\
\text { Disukai } \\
\text { Orang } \\
\text { Belanda }\end{array}$ \\
\hline 7 & $\begin{array}{l}15 \text { April } \\
2019\end{array}$ & $\begin{array}{l}\text { Berita / } \\
\text { Straight } \\
\text { News }\end{array}$ & $\begin{array}{l}\text { Cenderung } \\
\text { Lebih Suka }\end{array}$ \\
\hline
\end{tabular}

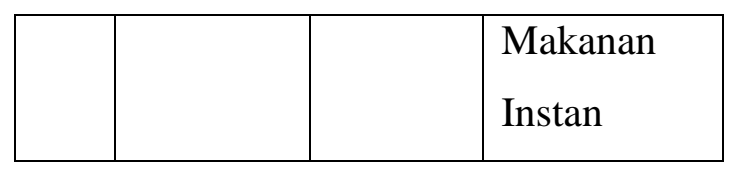

Tabel: 1 *) Sumber diolah: Harian Radar Jember

\begin{tabular}{|c|l|l|l|}
\hline No & $\begin{array}{l}\text { Tanggal } \\
\text { Terbit }\end{array}$ & $\begin{array}{l}\text { Jenis } \\
\text { Berita }\end{array}$ & $\begin{array}{l}\text { Judul } \\
\text { Berita }\end{array}$ \\
\hline 1 & $\begin{array}{l}27 \\
\text { Novembe } \\
\text { r } 2018\end{array}$ & $\begin{array}{l}\text { Berita / } \\
\text { Straight } \\
\text { News }\end{array}$ & $\begin{array}{l}\text { Delapan } \\
\text { UMKM } \\
\text { Jember } \\
\text { Diaudit } \\
\text { Halal }\end{array}$ \\
\hline 2 & $\begin{array}{l}03 \\
\text { Desembe } \\
\text { r 2018 }\end{array}$ & $\begin{array}{l}\text { Berita / } \\
\text { Straight }\end{array}$ & $\begin{array}{l}\text { Bupati Buk } \\
\text { a Road to } \\
\text { ISEF 2018 } \\
\text { Harus Bisa } \\
\text { Kembangk } \\
\text { an UMKM } \\
\text { dan } \\
\text { Ekonomi } \\
\text { Syariah }\end{array}$ \\
\hline 3 & $\begin{array}{l}08 \\
\text { Desembe } \\
\text { r 2018 }\end{array}$ & $\begin{array}{l}\text { Opini / } \\
\text { Artikel }\end{array}$ & $\begin{array}{l}\text { Menuju } \\
\text { Ekonomi } \\
\text { Halal } \\
\text { Oleh: } \\
\text { Khairunnis } \\
\text { a Musari }\end{array}$ \\
\hline 4 & $\begin{array}{l}\text { Januari } \\
2019\end{array}$ & $\begin{array}{l}\text { Berita / } \\
\text { Straight } \\
\text { Mahasiswa } \\
\text { News } \\
\text { Universitas } \\
\text { Muhammad } \\
\text { iyah Jember } \\
\text { Dorong } \\
\text { UMKM } \\
\text { Ajukan } \\
\text { Sertifikat } \\
\text { Halal }\end{array}$ \\
\hline
\end{tabular}

Tabel: $2 *$ ) Sumber diolah: Harian Radar Jember

Berbeda dengan media cetak, (Harian Radar Jember), untuk media televisi, khususnya Trans TV, TV One, dan Net $\mathrm{TV}$, serta televisi nasional lainnya, dalam 
peranannya memublikasi produk makanan halal, hampir seluruhnya menggunakan media iklan. Publikasi dalam bentuk berita, frekuensinya sangat terbatas, kecuali ada peristiwa atau kasus tertentu yang menyangkut produk makanan yang disinyalir tidak memenuhi syarat kehalalan. Seperti berita ditemukannya kasus jual-beli ayam "tiren" (mati kemarin), ayam "gelonggongan" atau praktik curang lainnya yang dilakukan pedagang, menjelang hari-hari besar keagamaan atau hari besar nasional lainnya.

Produk halal yang ditayangkan di televisi nasional, sebagian besar dalam bentuk iklan. Dan iklan terkait produk halal ini pun, tidak dalam bentuk dialog verbal, namun hanya berupa logo Halal dari LPPOM MUI, yang ditempelkan begitu saja diakhir tayangan gambar produk yang diiklankan.

Dari pengamatan peneliti, produk halal yang diiklankan di televisi cukup beragam, mulai produk shampoo dalam berbagai merek, produk sabun muka/pembersih wajah, produk kecantikan, hingga makanan dan minuman. Namun, jumlah produk terbanyak yang ditayangkan di televisi yang menggambarkan produk halal, justru produk shampoo, sabun muka/wajah, dan produk kecantikan lainnya. Untuk produk makanan dan minuman yang diiklankan sebagai produk halal, jumlah itemnya masih sangat terbatas. Dan itu berlaku untuk semua televisi nasional, mengingat produk yang ditayangkan nyaris sama, hanya frekuensi penayangannya saja yang berbeda di masing-masing televisi.

Sebenarnya media televisi mempunyai peran yang sangat strategis dalam memublikasikan produk halal ketengah masyarakat. Selain dalam bentuk iklan yang secara rutin di tayangkan --dan iklan yang berbayar ini tentu menjadi pemasukan utama perusahaan penyiaran. Sebagai media yang menggunakan hak publik, yakni memanfaatkan kanalfrequensi, media televisi seharusnya dapat berperan lebih besar lagi dalam ikut serta mensosialisasikan produk makanan halal, melalui berbagai program siaran, seperti dialog interaktif / talk show, program liputan investigasi, dan program berita lainnya.

Namun dari pengamatan peneliti selama periode penelitian, belum ada stasiun televisi yang menjadi objek penelitian menayangkan program acara dimaksud. Meski demikian, bukan berarti stasiun televisi tidak ada yang mempunyai program publikasi makanan halal. Di beberapa stasiun televisi sudah ada yang 
membahas tentang hal ini, namun waktu penayangannya jauh sebelum program ini diteliti, dan pokok bahasan yang menjadi perbincangan, bukan menyangkut produk makanan halal sesuai ketentuan UndangUndang Jaminan Produk Halal No. 33/2014 yang akan berlaku efektif Oktober 2019 mendatang.

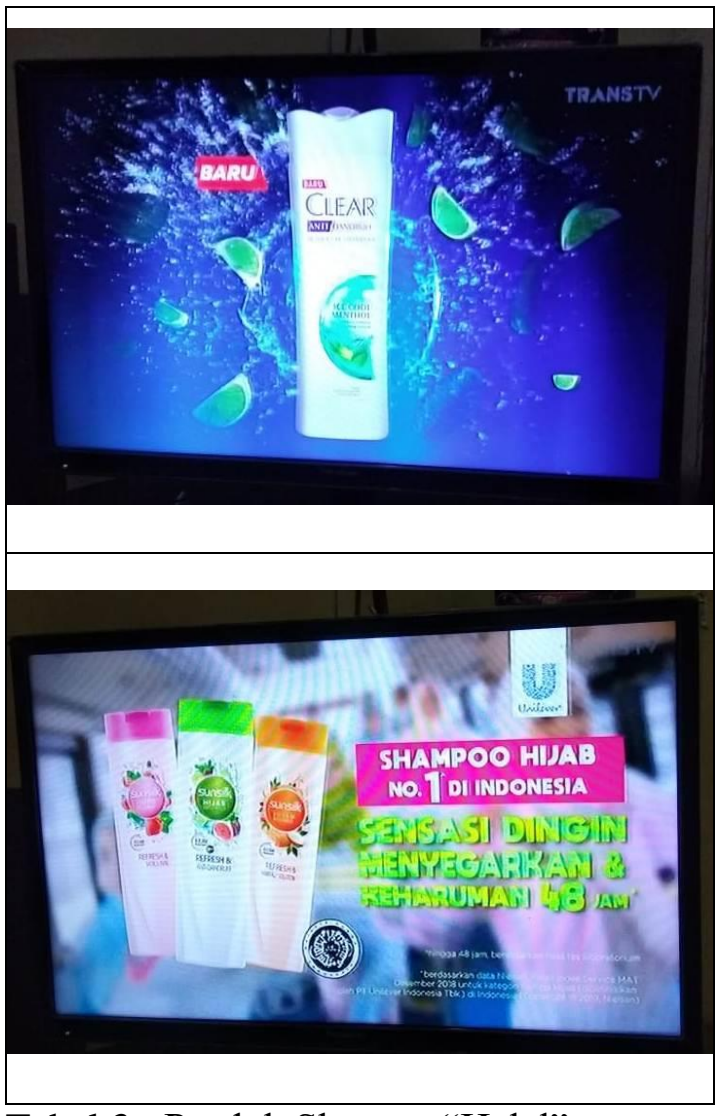

Tabel 3 : Produk Shampo "Halal"

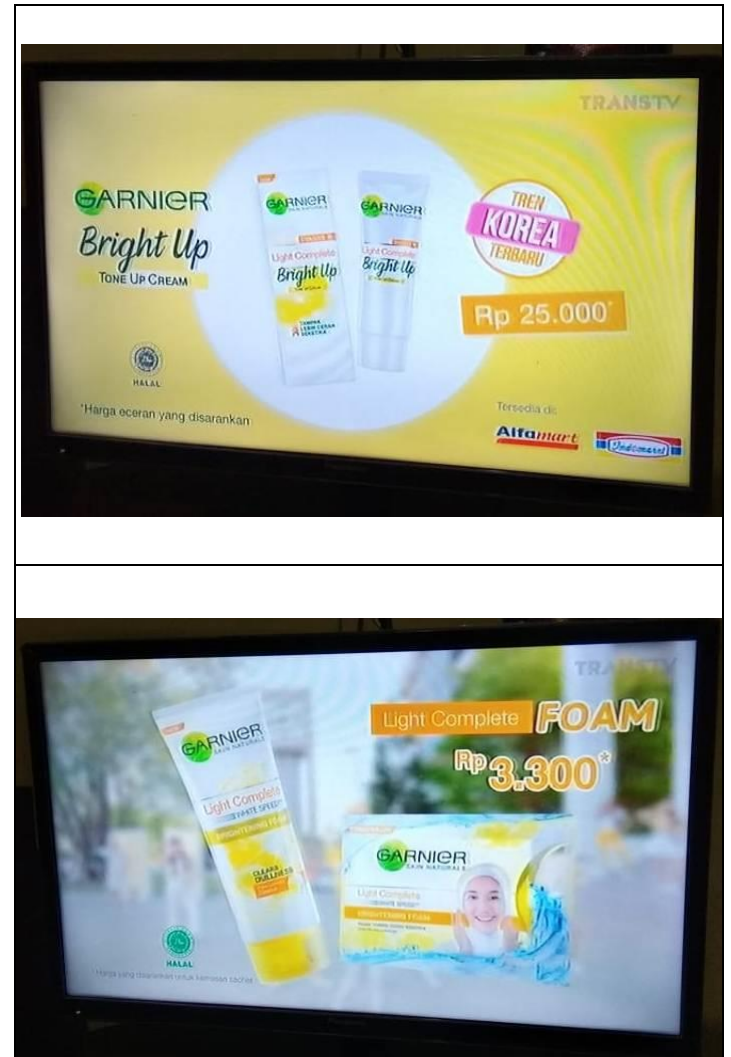

Tabel 4 : Produk Pembersih Muka "Halal"
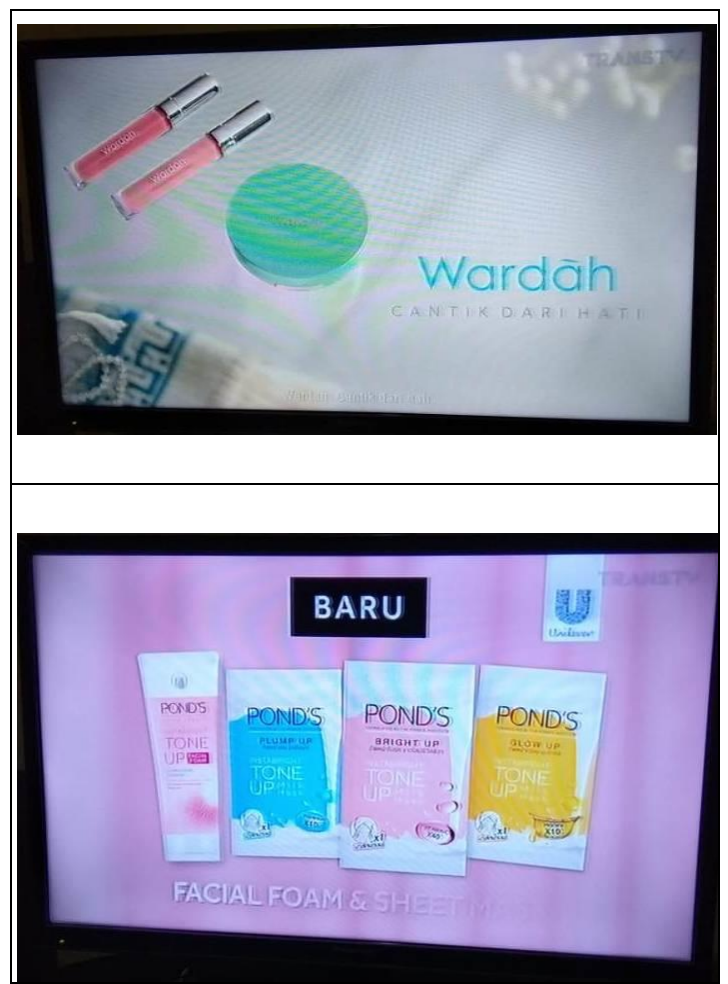

Tabel 5 : Produk Kosmetik "Halal" 


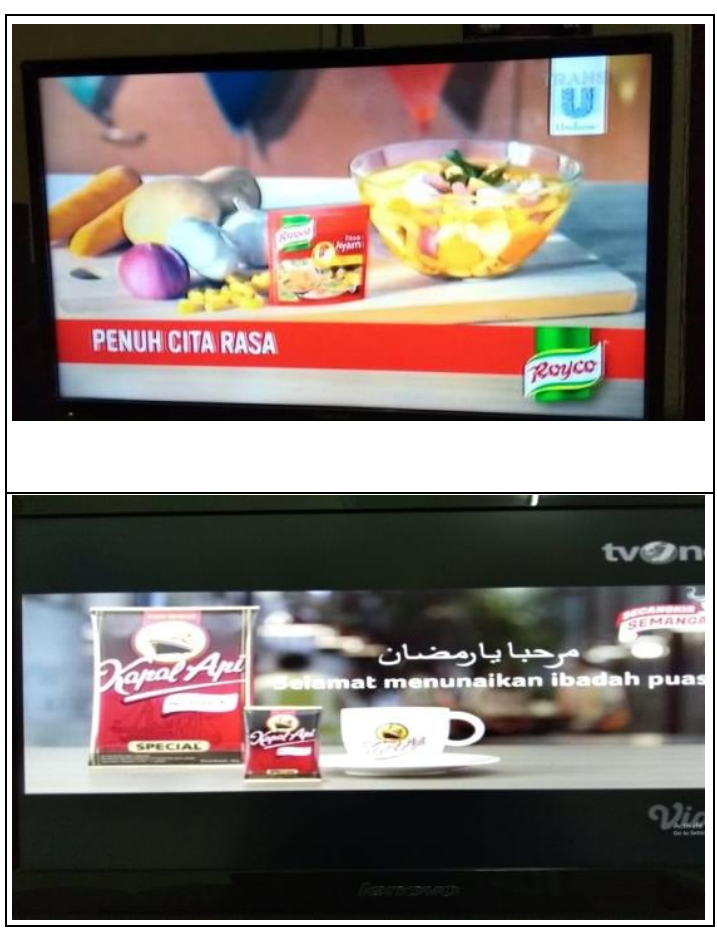

Tabel 6 Produk Makanan Halal

Meski peran media arus utama dalam memublikasikan produk makanan halal masih belum maksimal, namun Majelis Ulama Indonesia melalui lembaga LPPOM-MUI, terus mensosialisasikan perkembangan perusahaan yang sudah mengurus sertifikasi kehalalan produk perusahaannya, berikut macam produk makanan dan minuman olahan yang sudah dinyatakan tersertifikasi halal.

Melalui website dan media sosial lainnya, LPPOM-MUI aktif meng-update, perkembangan jumlah perusahaan yang sudah tersertifikasi. Bahkan LPPOM-MUI juga telah men-share prosedur dan tatacara melakukan pendaftaran dan prasarat pensertifikatan produk dari usaha masyarakat.
Melalui akun www.http://lppommui. surabaya atau www.http://halalmui.org misalnya, LPPOM-MUI memberi petunjuk persyaratan sertifikasi hala. HAS 23000 adalah dokumen yang berisi persyaratan sertifikasi halal LPPOM-MUI. HAS 23000 terdiri dari dua bagian, yaitu bagian pertama tentang persyaratan sertifikasi halal: Kriteria Sistem Jaminan Halal (HAS 23000:1) dan bagian kedua tentang persyaratan sertifikasi halal: Kebijakan dan Prosedur (HAS 23000:2). Bagi perusahaan yang ingin mendaftarkan sertifikasi halal ke LPPOM MUI, baik industri pengolahan (pangan, obat, kosmetika), Rumah Potong Hewan (RPH), restoran, katering, dapur, maka harus memenuhi persyaratan sertifikasi halal yang tertuang dalam dokumen HAS 23000.

DATA SERTIFIKASI HALAL LPPOM MUI PUSAT PERIODE 2012 - OKT 2017

\begin{tabular}{|c|c|c|c|}
\hline TAHUN & $\begin{array}{c}\text { JUMLAH } \\
\text { PERUSA } \\
\text { HAAN }\end{array}$ & $\begin{array}{c}\text { JUMLAH } \\
\text { SERTIFIKAT } \\
\text { HALAL }\end{array}$ & $\begin{array}{c}\text { JUMLAH } \\
\text { PRODUK }\end{array}$ \\
\hline 2012 & 626 & 653 & 19830 \\
\hline 2013 & 913 & 1092 & 34634 \\
\hline 2014 & 960 & 1310 & 40684 \\
\hline 2015 & 1052 & 1404 & 46260 \\
\hline 2016 & 1335 & 1789 & 65594 \\
\hline Okt - 2017 & 1169 & 1516 & 52982 \\
\hline & & & \\
\hline TOTAL & 6055 & 7764 & 259984 \\
\hline
\end{tabular}

Tabel: 7 Sumber: LPPOM-MUI Jatim 


\section{DATA SERTIFIKASI HALAL \\ LPPOM MUI \\ JANUARI - OKTOBER 2017}

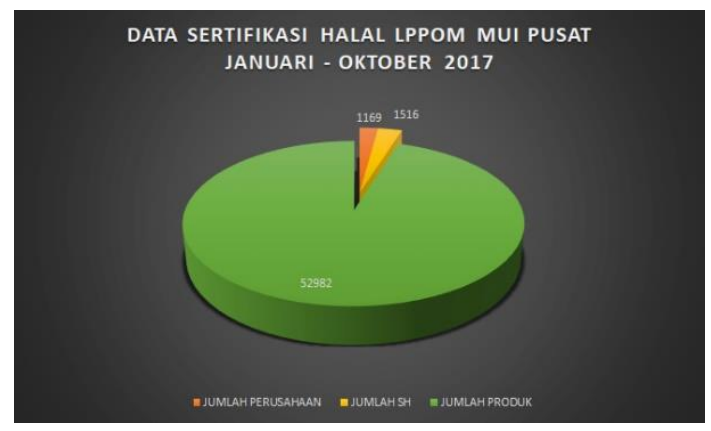

Tabel 8 Sumber: LPPOM-MUI Prov. Jawa Timur

DATA SERTIFIKASI HALAL

LPPOM MUI PUSAT

PERIODE 2012 - OKT 2017

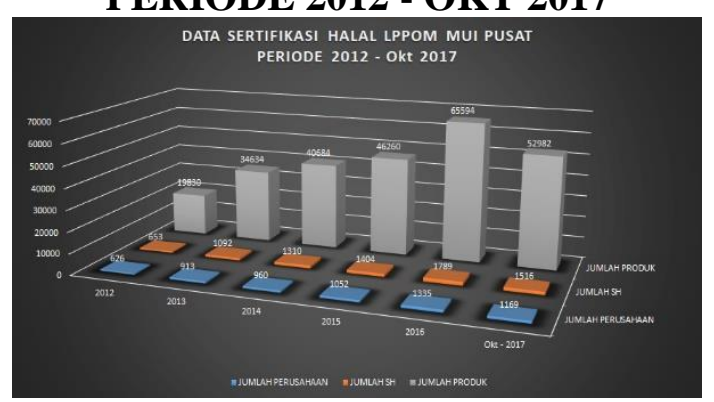

Tabel 9

DATA SERTIFIKASI HALAL LPPOM MUI PROVINSI JAWA TIMUR

PERIODE 2012 - 2016

\begin{tabular}{|c|c|c|c|}
\hline TAHUN & $\begin{array}{c}\text { JUMLAH } \\
\text { PERUSA } \\
\text { HAAN }\end{array}$ & $\begin{array}{c}\text { JUMLAH } \\
\text { SERTIFIKAT } \\
\text { HALAL }\end{array}$ & $\begin{array}{c}\text { JUMLAH } \\
\text { PRODUK }\end{array}$ \\
\hline 2012 & 5203 & 5504 & 13060 \\
\hline 2013 & 5753 & 5922 & 29487 \\
\hline 2014 & 9219 & 9009 & 27945 \\
\hline 2015 & 6888 & 7272 & 30996 \\
\hline 2016 & 5229 & 5603 & 48668 \\
\hline 2017 & - & - & - \\
\hline 2018 & - & - & - \\
\hline TOTAL & $\mathbf{3 2 2 9 2}$ & $\mathbf{3 3 3 1 0}$ & $\mathbf{1 5 0 1 5 6}$ \\
\hline
\end{tabular}

Tabel 10 Sumber: LPPOM-MUI Provinsi Jawa Timur
DATA SERTIFIKASI HALAL LPPOM-MUI PROVINSI JAWA TIMUR PERIODE 2012 - 2016

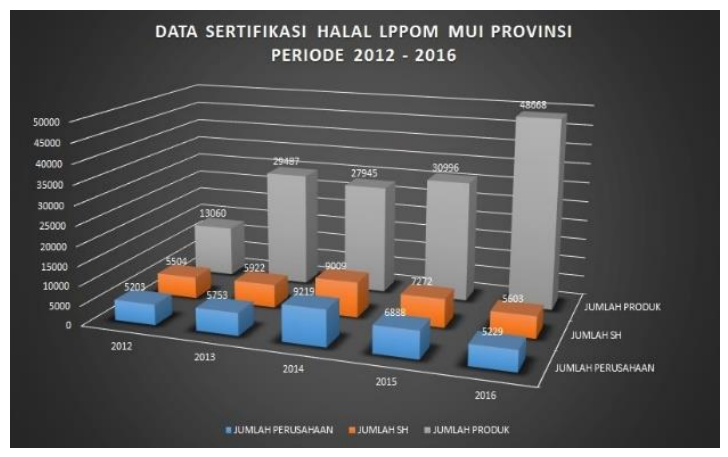

Sumber: LPPOM-MUI Provinsi Jawa Timur

\section{Simpulan}

Undang-Undang (UU) Nomor 33 Tahun 2014 tentang Jaminan Produk Halal (JPH), akan diberlakukan pada 17 Oktober 2019. Itu artinya semua produk makanan, minumanm, dan obat-obatan / kosmetik yang beredar dipasaran harus memenuhi ketentuan undang-undang tersebut. Halaltidaknya suatu produk menurut ketentuan undang-undang JPH, harus dibuktikan dengan adanya sertifikat halal yang dikeluarkan oleh lembaga yang ditunjuk, dalam hal ini LPPOM-MUI. Undangundang ini jelas berguna untuk melindungi konsumen Muslim terhadap produk makanan dan minuman yang tidak halal, disamping memberikan rasa aman dan nyaman.

Namun sejauh ini, gaung produk halal di kalangan konsumen, belumlah menggema nyaring, meski pihak MUI dan LPPOM sudah berupaya 
mensosialisasikan ketentuan JPH beberapa tahun silam. Hal ini terbukti dengan masih minimnya produk makanan, minuman, dan produk lainnya yang sudah mengantongi sertifikat halal. Karena itu, perlu peran media arus utama (mainstream) untuk membantu publikasi yang lebih massif lagi, sehingga mampu menggugah kesadaran masyarakat untuk mengonsumsi produk makanan, minuman dan produk lainnya, hanya yang sudah berlabel halal yang dibuktikan dengan telah dikantonginya sertifikat halal oleh pihak produsen.

Karena itu dibutuhkan upaya serius dari semua pihak, terutama dari pemerintah yang diwakili LPPOM MUI untuk lebih mengintensifkan publikasi melalui media arus utama (mainstream), terkait dengan sosialisasi dan promosi produk makanan halal.

\section{DAFTAR PUSTAKA}

Arikunto, Suharsimi. (2010). Prosedur Penelitian, Suatu Pendekatan Praktik. Jakarta. Rineka Cipta.

Badjuri, Adi. (2010). Jurnalistik Televisi. Yogyakarta. Graha Ilmu.

Bungin, Burhan. (2006). Sosiologi Komunikasi. Jakarta: Kencana PrenadaMedia Grup.

Kriyantono, Rachmat. (2014). Teknik Praktis Riset Komunikasi. Jakarta: Kencana Prenadamedia Group.

McQuail, Denis. (2000). Mass communication theories. Fourth Edition. London: Sage Publication.

Sobur, Alex. (2009). Semiotika Komunikasi. Bandung: PT Remaja Rosdakarya.

Sumarno, Karimah K., dan Damayanti NA. (2000). Filsafat dan Etika Komunikasi. Jakarta:

Universitas Terbuka Press.

\section{Sumber lain:}

Majalah Jurnal Halal edisi 127

\section{Website:}

www.http://lppommui.surabaya www.http://halalmui.org www.http://e-lppommui.org/. 